\title{
Chemical Speciation and Mobility of Heavy Metals in the Sediments of Selected Streams in Ibadan Metropolis, Nigeria
}

\author{
I. A. Ladigbolu \\ Department of Physical \& Chemical Oceanography Nigerian Institute for Oceanography \& Marine Research, \\ Victoria Island, Lagos
}

\begin{abstract}
Speciation of the following heavy metals, Cadmium (Cd), Chromium (Cr), Cobalt (Co), Copper (Cu), Lead (Pb), Nickel (Ni) and Zinc (Zn) were studied in the sediments of five streams in Ibadan metropolis namely Odo - ona (S-1), Ogunpa (S-2), Ogbere (S-3), Kudeti (S-4) and Gege (S-5). Highest percentage (\%) of Cr, Co and $\mathrm{Ni}$ were observed in the residual fraction, followed by $\mathrm{Cu}$ and $\mathrm{Cd}$ in the oxidisable fraction and $\mathrm{Zn}$ and $\mathrm{Pb}$ in the reducible fraction. Exchangeable fraction contributed the least $\%$ of all the metals studied except in the (S-1) where the \% metals contribution of exchangeable fraction was more than that of carbonate bound fraction. The presence of more than $50 \%$ of $\mathrm{Pb}, \mathrm{Cd}, \mathrm{Cu}, \mathrm{Zn}$ in non - lithogenous phase of all the studied streams, Co in (S-1) and Ni in (S-2) indicates the influence of anthropogenic activities. Their readily availability for plants and aquatic biota uptakes also suggested greater environmental risks. $\mathrm{Cr}, \mathrm{Co}$ and $\mathrm{Ni}$ in all the studied streams of Ibadan metropolis were influenced by rock and soils formation (weathering) except Co and Ni in $\mathrm{S}-1$ and $S-2$ streams respectively. However, their unavailability for uptakes indicated no environmental risks under natural conditions.
\end{abstract}

Keywords: Speciation, heavy metals, environmental risks, lithogenous, sediments

\section{Introduction}

Chemical speciation of metals in the sediments is the identification and quantification of different forms and process in which metals can occur in the sediments (Xian X, 1989). It can also be referred to as the study of chemical minerals in the sediment samples through which metals in the sediment are usually separated into different geological phases with varying mobility, leachability and bioavailability.

The geological phases in which metals exist in the sediment can be classified into two major groups, lithogenous / residual fraction and non-lithogenous fraction. Lithogenous or residual fraction metals are not available in long term for bio - uptake, due to strong bond which exists between these metals and crystal lattice of silicate of the sediments and soils. Therefore, they are from natural source that is rock or soils weathering while non- lithognous fractions metals are readily available in short term (Badri and Anston, 1983).

Non-lithogenous (mobile) fraction can be further subdivided into exchangeable fraction, carbonate bound fraction, reducible (Fe-Mn oxides / hydroxides) fraction and oxidisable (organic matter / sulphide) fraction (O'Neill et al; 1981).Metals associated with the four fractions that make up the non - lithogenous fraction most of time comes from anthropogenic sources and they are more available for uptakes and bioaccumulation in aquatic biota, although their availability is many a time $\mathrm{pH}$, redox- potential and temperature dependent (Gambrell, 1994, and Schlinder, 1991).

Furthermore, effective characterization of the behaviour of heavy metals in the sediment require both the knowledge of total heavy metals concentration and chemical speciation (Zauyah et. al; 2004), because information obtained from them would give an insight into the environmental impact of these metals and reliably predicts their sources \{i.e. anthropogenic and natural (rock or soil weathering)\}, mobility, bioavailability, distribution and toxicity in the environment.

The orientation of this study is to study the speciation of the following heavy metals; $\mathrm{Zn}, \mathrm{Cu}, \mathrm{Cd}, \mathrm{Ni}$, $\mathrm{Pb}, \mathrm{Cr}$ and $\mathrm{Co}$ in the sediments of the following five (5) important multipurpose streams / Rivers of Ibadan metropolis; Odo-ona (S-1), Ogunpa (S-2), Ogbere (S-3), Kudeti (S-4) and Gege (S-5) to establish the quantity and distribution patterns of the severally reported heavy metals in the sediment of each of the above mentioned streams for proper understanding of their biogeochemical processes, bioavailability and their tendency to cause health hazard.

\section{Study Area}

\section{Materials and Methods}

The study areas are Ogunpa, Gege, Odo-ona, Ogbere and Kudeti streams in Ibadan metropolis. Ibadan metropolis is located at latitude $7^{\circ} 21^{\prime} \mathrm{N}$ and longitude $3^{\circ} 53^{\prime} \mathrm{E}$, about $110 \mathrm{~km}$ northeast of Lagos, Nigeria. The study area is characterized by tropical humid climate with two distinct seasons: the wet season which occurs between March and October with an average annual rainfall of about 1,250mm and dry season from November 
to February characterized by dry, dusty and relatively cold NE-SW trade winds. Ibadan metropolis is characterized by high population density of about 3,250 persons per sq. kilometer in comparison to the national average of 137 persons per sq. kilometer(Tijani et al;2004). Other peculiar features of the Ibadan metropolis are poor land- use planning, lack of adequate water supply and sanitary conditions, lack of proper sewage and waste disposal systems, traffic congestion and direct dumping of domestic refuse and sewage water into the streams and rivers within the metropolis and its environs (Fig. 1).

\section{Figure 1}

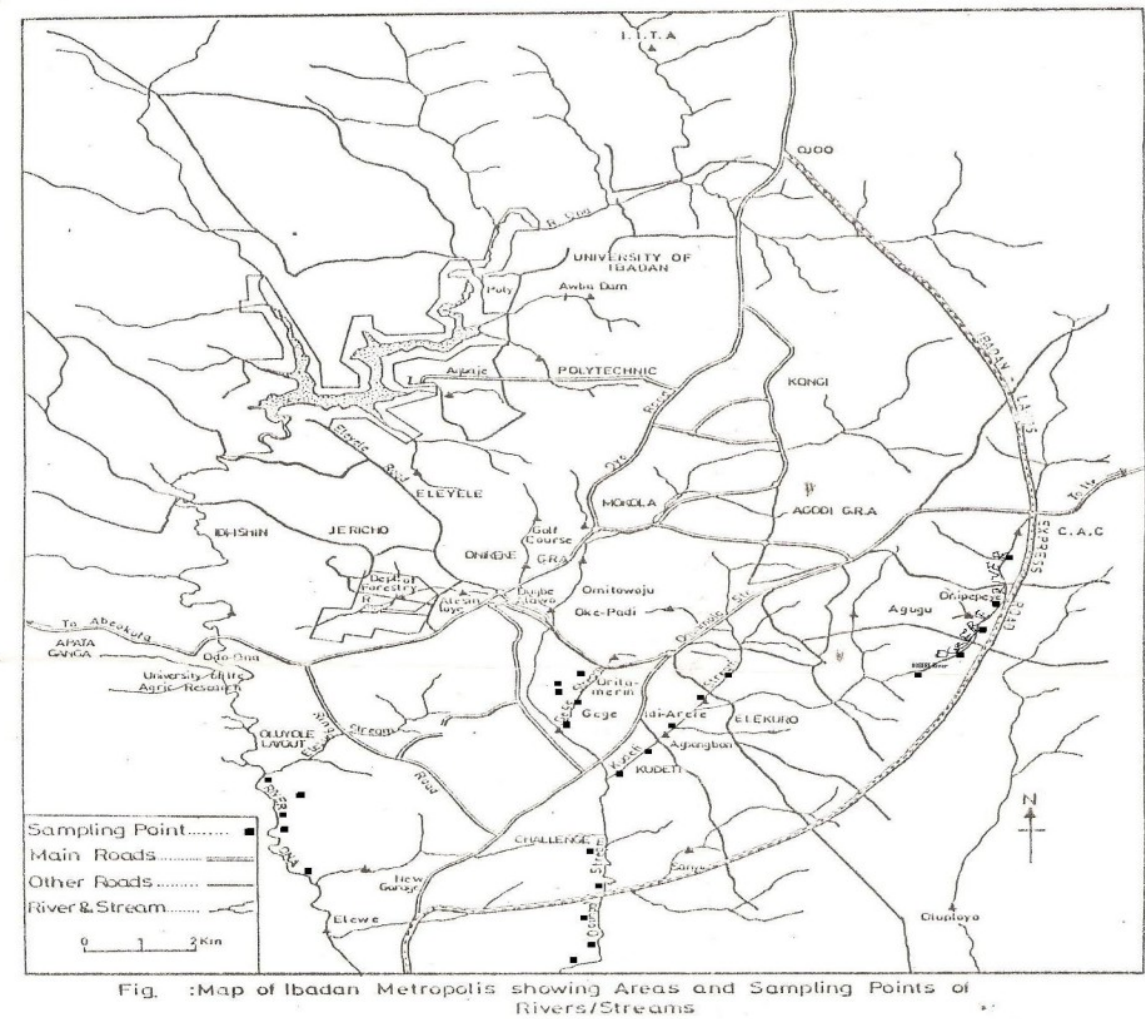

\section{Sample collection:}

Sediment samples were collected at the sampling location shown in the Map (Figure 1) with an average of five samples collected along each of the five studied streams; Odo-ona, Ogunpa, Ogbere Kudeti and Gege streams.

These sediments were collected in the dry season (April, 1998) with aids of van-veen grab and stored in well labelled black polythene bags that have been previously soaked in $10 \% \mathrm{HNO}_{3}$ (Nitric acid) and 1:1 $\mathrm{HCl}$ (Hydrochloric acid) for $24 \mathrm{hrs}$ followed by rinsing with distilled water and then allowed to drain to dryness.

\section{Metal Analysis:}

The five sediment samples collected along each of the streams were air dried, thoroughly mixed together, grinded using mortar and pestle and sieved through $2 \mathrm{~mm}$ mesh size to remove coarse materials. Then $5 \mathrm{~g}$ of each of the $2 \mathrm{~mm}$ mesh size sieved sediment samples from each of the five stream were digested separately to obtain the total concentration of the metals (Anderson, 1979) and the metals $(\mathrm{Cu}, \mathrm{Cd}, \mathrm{Cr}, \mathrm{Co}, \mathrm{Pb}, \mathrm{Ni} \& \mathrm{Zn}$ ) were analyzed using Buck scientific 200A model (AA-ES) Atomic absorption spectrophotometer (AAS).

\section{Metal speciation analyses}

$1 \mathrm{~g}$ of the already air dried, thoroughly mixed, well grinded and sieved sediment samples representing each of the study streams were separately sequentially extracted in a centrifuge tube using a centrifuge machine. Solution obtained from each stages of the sequential extraction were neatly decanted into a well labelled pretreated plastic bottles and later analyzed using scientific model 200A (AA-ES) Atomic Absorption spectrophotometer (AAS) (Tessier et al, 1979).

Sequential extraction: The sequential extraction of trace elements was carried out as per Tessier et al., [1979]. $1 \mathrm{~g}$ sediment was extracted in the following order: 
Fraction 1: Dissolved or Exchangeable fraction: $1 \mathrm{M}$ magnesium chloride $(25 \mathrm{ml}), \mathrm{pH} 7.01$ shaking for $1 \mathrm{hr}$ at $25^{0} \mathrm{C}$.

Fraction 2: Carbonate bound fraction (acid soluble): $1 \mathrm{M}$ sodium acetate $(25 \mathrm{ml}), \mathrm{pH} 5.04$ with acetic acid, $6 \mathrm{hr}$ shaking at $25^{\circ} \mathrm{C}$.

Fraction 3: Fe-Mn oxide bound fraction (reducible): $0.04 \mathrm{M}$ hydroxylamine hydrochloride in acetic acid (25\% $\mathrm{v} / \mathrm{v}), 25 \mathrm{ml}$, shaking $6 \mathrm{hr}$ at $96^{\circ} \mathrm{C}$.

Fraction 4: Organic bound fraction (oxidizable): $0.02 \mathrm{M}$ nitric acid $(6 \mathrm{ml})+30 \%$ hydrogen peroxide $(9 \mathrm{ml}), 2$ hrs occasional shaking at $85^{\circ} \mathrm{C}$, additional $9 \mathrm{ml}$ of $30 \%$ hydrogen peroxide with continuation of shaking at $85^{\circ} \mathrm{C}$ for 3 hrs.

Fraction 5: Residual fraction (bound to silicates and detritus materials): Total digestion with concentrated mixture of nitric acid and perchloric acid $(3: 1 \mathrm{v} / \mathrm{v})$

\section{Results and Discussion}

Table 1: Results of Heavy metals Speciation in the sediment of Ibadan Streams ( $\mu \mathrm{g} / \mathrm{g}$ dry. wt)

\begin{tabular}{|c|c|c|c|c|c|c|c|c|c|}
\hline Streams & $\begin{array}{l}\text { Metal } \\
\text { s }\end{array}$ & $\begin{array}{l}\text { Exchangeabl } \\
\text { e }\end{array}$ & $\begin{array}{l}\text { Carbonat } \\
\text { e }\end{array}$ & $\begin{array}{l}\text { Reducibl } \\
\text { e }\end{array}$ & Oxidisable & Residual & $\begin{array}{l}\text { Total } \\
\text { conc. } \\
\text { from the } \\
\text { Fractions }\end{array}$ & $\begin{array}{l}\text { Total } \\
\text { conc. } \\
\text { From } \\
\mathrm{HNO}_{3}\end{array}$ & $\begin{array}{l}\% \\
\text { Recovery } \\
\text { for } \mathrm{HNO}_{3}\end{array}$ \\
\hline \multirow{7}{*}{$\begin{array}{l}\text { Odo-ona } \\
(\mathrm{S}-1)\end{array}$} & $\mathrm{Zn}$ & 67.20 & 3.20 & 17.00 & 7.00 & 89.50 & 183.90 & 177.10 & 88 \\
\hline & $\mathrm{Cu}$ & 8.00 & 3.44 & 5.40 & 21.20 & 11.50 & 49.50 & 38.90 & \\
\hline & $\mathrm{Ni}$ & 0.688 & 0.248 & 0.24 & 5.62 & 6.88 & 13.68 & 10.80 & \\
\hline & $\mathrm{Cd}$ & 0.109 & 0.075 & 0.124 & 0.26 & 0.22 & 0.79 & 0.89 & 105 \\
\hline & $\mathrm{Pb}$ & 8.00 & 2.40 & 6.00 & 20.00 & 17.50 & 53.90 & 53.00 & 82.8 \\
\hline & $\mathrm{Cr}$ & 0.488 & 1.24 & 2.82 & 3.58 & 29.30 & 37.43 & 27.60 & \\
\hline & $\mathrm{Co}$ & 12.80 & 1.60 & 2.20 & 1.00 & 17.30 & 34.90 & 26.10 & \\
\hline \multirow{7}{*}{$\begin{array}{l}\text { Ogunpa } \\
\text { (S-2) }\end{array}$} & $\mathrm{Zn}$ & 0.88 & 48.00 & 68.00 & 13.80 & 92.50 & 223.20 & 177.10 & 75 \\
\hline & $\mathrm{Cu}$ & 0.64 & 8.32 & 12.60 & 23.40 & 17.80 & 62.80 & 52.80 & \\
\hline & $\mathrm{Ni}$ & 0.32 & 0.504 & 1.70 & 6.10 & 6.20 & 14.90 & 14.40 & \\
\hline & $\mathrm{Cd}$ & 0.09 & 0.09 & 0.206 & 0.184 & 0.21 & 0.78 & 1.03 & 113.6 \\
\hline & $\mathrm{Pb}$ & 6.40 & 33.60 & 88.00 & 24.00 & 22.50 & 174.50 & 169.00 & 93.1 \\
\hline & $\mathrm{Cr}$ & 0.416 & 0.208 & 1.06 & 1.70 & 29.13 & 32.59 & 24.70 & \\
\hline & $\mathrm{Co}$ & 2.08 & 2.32 & 8.40 & 2.80 & 20.00 & 35.60 & 32.80 & \\
\hline \multirow{7}{*}{$\begin{array}{l}\text { Ogbere } \\
(\mathrm{S}-3)\end{array}$} & $\mathrm{Zn}$ & 5.36 & 37.60 & 40.00 & 8.80 & 72.90 & 164.70 & 153.10 & \\
\hline & $\mathrm{Cu}$ & 1.44 & 10.10 & 13.80 & 18.00 & 16.50 & 59.80 & 56.90 & \\
\hline & $\mathrm{Ni}$ & 0.288 & 0.512 & 0.420 & 4.04 & 11.85 & 17.11 & 11.30 & \\
\hline & $\mathrm{Cd}$ & 0.097 & 0.109 & 0.072 & 0.294 & 0.213 & 0.785 & 0.89 & \\
\hline & $\mathrm{Pb}$ & 8.00 & 16.80 & 40.00 & 6.00 & 20.00 & 90.80 & 73.00 & 89.4 \\
\hline & $\mathrm{Cr}$ & 0.45 & 0.392 & 3.00 & 40.60 & 79.50 & 87.40 & 67.20 & \\
\hline & $\mathrm{Co}$ & 1.84 & 2.40 & 6.00 & 0.80 & 17.00 & 28.00 & 17.00 & \\
\hline \multirow{7}{*}{$\begin{array}{l}\text { Kudeti } \\
\text { (S-4) }\end{array}$} & $\mathrm{Zn}$ & 1.20 & 51.20 & 58.00 & 15.00 & 60.00 & 185.40 & 165.10 & \\
\hline & $\mathrm{Cu}$ & 0.72 & 8.48 & 11.20 & 23.40 & 12.00 & 55.80 & 45.10 & \\
\hline & $\mathrm{Ni}$ & 0.24 & 0.400 & 0.720 & 5.52 & 9.30 & 16.18 & 13.10 & \\
\hline & $\mathrm{Cd}$ & 0.098 & 0.089 & 0.082 & 0.024 & 0.173 & 0.466 & 0.65 & \\
\hline & $\mathrm{Pb}$ & 7.20 & 16.00 & 62.00 & 18.00 & 15.00 & 118.20 & 81.00 & \\
\hline & $\mathrm{Cr}$ & 0.38 & 0.28 & 0.88 & 1.50 & 41.38 & 44.42 & 42.50 & \\
\hline & $\mathrm{Co}$ & 2.00 & 2.56 & 6.20 & 1.60 & 15.25 & 27.60 & 12.30 & \\
\hline \multirow{7}{*}{$\begin{array}{l}\text { Gege } \\
(\mathrm{S}-5)\end{array}$} & $\mathrm{Zn}$ & 2.40 & 232.00 & 114.00 & 15.60 & 72.50 & 436.50 & 429.10 & \\
\hline & $\mathrm{Cu}$ & 1.12 & 18.50 & 51.60 & 158.20 & 18.00 & 247.42 & 239.50 & \\
\hline & $\mathrm{Ni}$ & 0.28 & 0.68 & 0.54 & 1.08 & 12.50 & 15.08 & 14.90 & \\
\hline & $\mathrm{Cd}$ & 0.01 & 0.114 & 0.06 & 0.198 & 0.173 & 0.56 & 1.34 & \\
\hline & $\mathrm{Pb}$ & 7.20 & 143.20 & 262.00 & 138.00 & 35.00 & 585.40 & 419.00 & \\
\hline & $\mathrm{Cr}$ & 0.48 & 0.512 & 1.84 & 2.64 & 89.75 & 95.22 & 94.30 & \\
\hline & $\mathrm{Co}$ & 2.40 & 3.36 & 2.60 & 0.80 & 12.80 & 22.00 & 12.00 & \\
\hline
\end{tabular}

Table 2: Percentage of Heavy metals Speciation in the sediment of Ibadan Streams ( $\% \mu \mathrm{g} / \mathrm{g}$ dry. wt) 
Chemical Speciation and Mobility of Heavy Metals in the Sediments of Selected Streams in Ibadan

\begin{tabular}{|c|c|c|c|c|c|c|c|c|c|}
\hline Streams & Metals & $\begin{array}{l}\text { Exchangeable } \\
\text { fraction (1) in } \\
\%\end{array}$ & $\begin{array}{l}\text { Carbonate } \\
\text { fraction } \\
(2) \text { in } \%\end{array}$ & $\begin{array}{l}\text { Reducible } \\
\text { fraction } \\
\text { (3) in } \%\end{array}$ & $\begin{array}{l}\text { Oxidisable } \\
\text { fraction } \\
\text { (4) in } \%\end{array}$ & $\begin{array}{l}\text { Residual } \\
\text { fraction } \\
(5) \text { in } \%\end{array}$ & $\begin{array}{l}\text { Total } \\
\text { fractio } \\
\mathrm{ns}(\%) \\
\approx\end{array}$ & $\begin{array}{l}\text { Sum } \\
\text { of( } 1- \\
4) \%\end{array}$ & $\begin{array}{lr}\text { Remarks } & \text { on } \\
\text { likely bio- } \\
\text { available } \\
\text { metals }\end{array}$ \\
\hline \multirow{7}{*}{$\begin{array}{l}\text { Odo-ona } \\
\text { (S-1) }\end{array}$} & $\mathrm{Zn}$ & 38.0 & 1.8 & 9.6 & 4.0 & 46.6 & 100 & 53.4 & \\
\hline & $\mathrm{Cu}$ & 16.0 & 7.0 & 11.0 & 43.0 & 23.0 & 100 & 77.0 & \\
\hline & $\mathrm{Ni}$ & 5.0 & 1.8 & 1.8 & 41.1 & 50.3 & 100 & 49.7 & \\
\hline & $\mathrm{Cd}$ & 13.8 & 9.5 & 15.7 & 33.0 & 28.0 & 100 & 72.0 & \\
\hline & $\mathrm{Pb}$ & 14.8 & 4.5 & 11.1 & 37.1 & 32.5 & 100 & 67.5 & \\
\hline & $\mathrm{Cr}$ & 1.3 & 3.3 & 7.5 & 9.6 & 78.3 & 100 & 21.7 & \\
\hline & Co & 36.6 & 4.6 & 6.3 & 2.9 & 49.6 & 100 & 50.4 & \\
\hline \multirow{7}{*}{$\begin{array}{l}\text { Ogunpa } \\
\text { (S-2) }\end{array}$} & $\mathrm{Zn}$ & 0.4 & 21.5 & 30.5 & 6.2 & 41.4 & 100 & 58.6 & \\
\hline & $\mathrm{Cu}$ & 1.0 & 13.2 & 20.1 & 37.4 & 28.3 & 100 & 71.7 & \\
\hline & $\mathrm{Ni}$ & 2.2 & 3.4 & 11.4 & 41.0 & 42.0 & 100 & 58.0 & \\
\hline & $\mathrm{Cd}$ & 11.5 & 11.5 & 26.4 & 23.6 & 27.0 & 100 & 73.0 & \\
\hline & $\mathrm{Pb}$ & 3.6 & 19.3 & 50.1 & 14.0 & 13.0 & 100 & 87.0 & \\
\hline & $\mathrm{Cr}$ & 1.3 & 1.0 & 3.3 & 5.2 & 89.2 & 100 & 10.8 & \\
\hline & $\mathrm{Co}$ & 5.8 & 6.5 & 23.6 & 8.0 & 56.1 & 100 & 43.9 & \\
\hline \multirow{7}{*}{$\begin{array}{l}\text { Ogbere } \\
(\mathrm{S}-3)\end{array}$} & $\mathrm{Zn}$ & 3.1 & 23.0 & 24.3 & 5.3 & 44.3 & 100 & 55.7 & \\
\hline & $\mathrm{Cu}$ & 2.3 & 17.0 & 23.1 & 30.1 & 27.5 & 100 & 72.5 & \\
\hline & $\mathrm{Ni}$ & 1.7 & 3.0 & 2.5 & 23.5 & 69.3 & 100 & 30.7 & \\
\hline & $\mathrm{Cd}$ & 12.3 & 14.0 & 9.2 & 37.4 & 27.1 & 100 & 72.9 & \\
\hline & $\mathrm{Pb}$ & 8.8 & 18.5 & 44.1 & 6.6 & 22.0 & 100 & 88.0 & \\
\hline & $\mathrm{Cr}$ & 0.5 & 0.4 & 3.4 & 4.7 & 91.0 & 100 & 9.0 & \\
\hline & $\mathrm{Co}$ & 6.5 & 8.5 & 21.4 & 3.0 & 61.6 & 100 & 38.4 & \\
\hline \multirow{7}{*}{$\begin{array}{l}\text { Kudeti } \\
\text { (S-4) }\end{array}$} & $\mathrm{Zn}$ & 0.6 & 27.6 & 31.3 & 8.1 & 32.4 & 100 & 67.6 & \\
\hline & $\mathrm{Cu}$ & 1.3 & 15.2 & 20.1 & 41.9 & 21.5 & 100 & 78.5 & \\
\hline & $\mathrm{Ni}$ & 1.5 & 2.5 & 4.4 & 34.1 & 57.5 & 100 & 42.5 & \\
\hline & $\mathrm{Cd}$ & 21.1 & 19.1 & 17.6 & 5.2 & 37.0 & 100 & 63.0 & \\
\hline & $\mathrm{Pb}$ & 6.1 & 13.5 & 52.5 & 15.2 & 12.7 & 100 & 87.3 & \\
\hline & $\mathrm{Cr}$ & 0.9 & 0.6 & 2.0 & 3.4 & 93.1 & 100 & 6.9 & \\
\hline & $\mathrm{Co}$ & 7.2 & 9.3 & 22.5 & 5.8 & 55.2 & 100 & 44.8 & \\
\hline \multirow{7}{*}{$\begin{array}{l}\text { Gege } \\
(\mathrm{S}-5)\end{array}$} & $\mathrm{Zn}$ & 0.5 & 53.2 & 26.1 & 3.6 & 16.6 & 100 & 83.4 & \\
\hline & $\mathrm{Cu}$ & 0.8 & 12.5 & 14.0 & 60.5 & 12.2 & 100 & 87.8 & \\
\hline & $\mathrm{Ni}$ & 1.9 & 4.5 & 3.6 & 7.2 & 82.8 & 100 & 17.2 & \\
\hline & $\mathrm{Cd}$ & 15.4 & 17.7 & 9.3 & 30.7 & 26.9 & 100 & 73.1 & \\
\hline & $\mathrm{Pb}$ & 1.2 & 24.5 & 44.8 & 23.5 & 6.0 & 100 & 94.0 & \\
\hline & $\mathrm{Cr}$ & 0.5 & 0.6 & 2.0 & 3.0 & 93.9 & 100 & 6.1 & \\
\hline & $\mathrm{Co}$ & 11.0 & 15.3 & 12.0 & 3.6 & 58.1 & 100 & 41.9 & \\
\hline
\end{tabular}

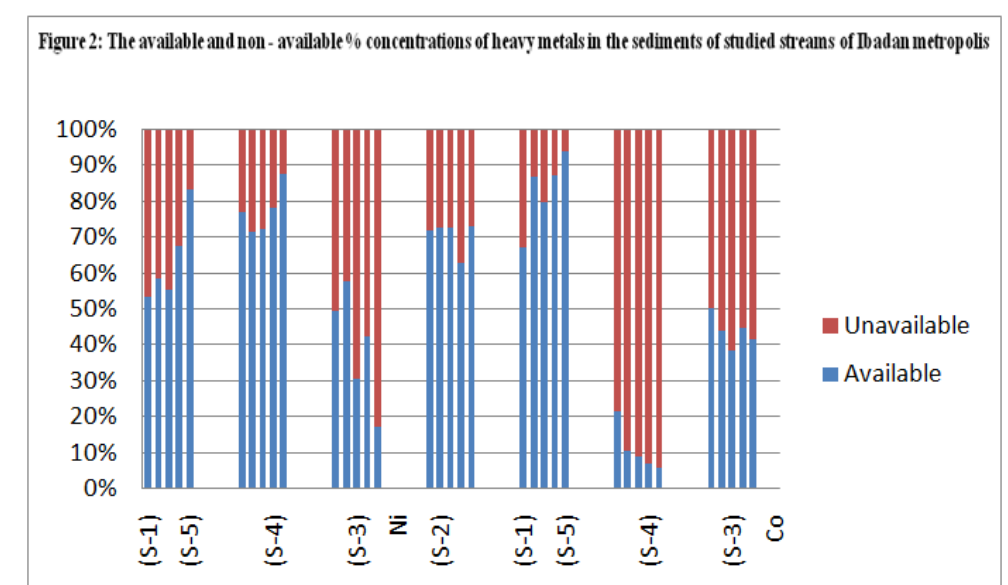

Figure 2: Represent the available and non - available \% concentration of heavy metals in the sediments of the studied streams. 


\section{Geochemical Partitioning of trace metals in the sediment of studied streams}

The geochemical distribution patterns of studied metals in the sediment of studied streams as obtained in the present sequential extraction procedure were as discussed below (Table $1 \& 2$ ). It showed the relative scavenging action of discrete sediment phases and their bioavailability possibility in the studied streams.

\section{Zinc (Zn)}

In the following five streams studied (S-1, S-2, S-3, S-4, S-5) high percentage of the total particulate $\mathrm{Zn}$ were found in Fe-Mn oxides (reducible); (10, 31, 24, 31 and 28\%), carbonates (2, 22, 23, 27 and 53\%) and oxidisable $(4,6,5,8$ and $4 \%$ ) whereas much lower percentage that less than $1 \%$ were found in exchangeable fraction except in the Odo-Ona (S-1) where $\mathrm{Zn}$ was found in high percentage at exchangeable fraction (38\%). The highest percentage of $\mathrm{Zn}$ were observed in residual fraction except for the Gege (S-5) in which it was lower as shown in the bracket $(47,41,44,32$ and 16\%) and Table 2 above. The abundance trend of $\mathrm{Zn}$ in Fe-Mn oxides (reducible) noticed in this study except in (S-1) in which percentage of Zn was considerably lower was in line with Grieve and Fletcher (1977) report that the proportion of total $\mathrm{Zn}$ associated with Fe-Mn oxides (reducible) increased from approximately $20 \%$ in fresh water zone to as much as $80 \%$ in brackish waters.

\section{Copper (Cu)}

High percentage of $\mathrm{Cu}$ were found in the residual (23, 28, 28, 22 and12), Fe-Mn oxide (reducible) (11, $20,23,20$ and 14) and carbonates $(7,13,17,15$ and 13) whereas much lower percentage that less than $2 \%$ was found in the exchangeable fraction except in the (S-1) in which the percentage of exchangeable fraction of $\mathrm{Cu}$ was $16 \%$. The highest percentages of studied metals were bound to oxidisable fraction $(43,37,30,42$ and 61$)$. This result can be explained by the fact that $\mathrm{Cu}$ can easily complex with organic matters to form high stability constant organic - Cu compounds (Haung et al., 2007, Ashraf et al., 2012, Smith and Mortell, 1976, Stumm and Morgan, 1970).

\section{Nickel (Ni)}

Highest percentage of $\mathrm{Ni}$ was found in the residual fraction of the five studied streams sediment analyzed $(50,42,69,58$ and 83). These results were in agreement with those of other authors for fresh water or coastal marine sediments (Bramnon et al., 1976, Gupta and Chen, 1975). Furthermore, the percentage of residual Ni have been reported to decrease towards mid - ocean by Chester and Messiha - Hanna, 1970. High percentage distribution of $\mathrm{Ni}$ was also observed in the oxidisable fraction $(41,41,24,34$ and 7$)$ whereas the percentage contributions of the remaining fractions were observed low; exchangeable $(5,2.2,1.7,1.5$ and 1.9), carbonates $(1.8,3.4,3.0,2.5$ and 4.5$)$ and reducible $(1.8,11.4,2.5,4.4$ and 3.6).

\section{Cadmium (Cd)}

The highest percentage of total particulate $\mathrm{Cd}$ were found in the oxidisable fraction of all the studied streams sediment $(33,24,37,5$ and 31$)$ with exception of $(\mathrm{S}-4)$ in which organic fraction contributes the lowest percentage of $\mathrm{Cd}(5 \%)$. Residual fraction contributes high percentages of total particulate $\mathrm{Cd}$ next to oxidisable fraction $(28,27,27,37$ and 27) whereas the rest of the fractions such as exchangeable $(14,12,12,21$ and 15), carbonates $(10,12,14,19$ and 18) and reducible fraction $(2,9,5,9$ and 26) contributes moderately. These results contrast with those of Tessier et al., 1979 for the Yamaska and St. Francois rivers (Quebec) where the contribution of $\mathrm{Cd}$ bound to organic matter was undetectable, exchangeable (26 \& $28 \%$ ), carbonates (49 \& $31 \%$ ) and reducible (26 \& 28\%).

\section{Lead (Pb)}

The lowest percentage of total particulate $\mathrm{Pb}$ were found associated with exchangeable fraction $(15$, 3.6, 8.8, 6.1 and 1.2\%) except in a few case such (S-1) and (S-3) as shown in Table 1 \& 2. Moderate contribution were afforded by the carbonates $(5,19,19,14$ and 25), oxidisable (organic matter) $(37,14,6.6,15$ and 24$)$ and residual $(33,13,22,13$ and 6$)$ fractions whereas reducible fraction ( $\mathrm{Fe}-\mathrm{Mn}$ oxide) contributed the highest percentage of $\mathrm{Pb}(11,50,44,53$ and 46). The abundance of $\mathrm{Pb}$ bound to $\mathrm{Fe}-\mathrm{Mn}$ oxides in this present study were in agreement with the results of Gupta and Chen, 1975, Morgan \& Stumm, 1981 and Forstner \& Wittman, 1981 reports in which high concentration of $\mathrm{Pb}$ were found in ferromanganese modules.

\section{Chromium (Cr)}

The residual fraction contributed the highest percentage of $\mathrm{Cr}$ in all the streams sediment studied (78, 89, 91, 93 and 94), low contribution were observed in oxidisable (9, 5.3, 4.7, 3.4 and 3) and reducible (Fe $-\mathrm{Mn}$ oxides) $(7.5,7.3,3.4,2$ and 2$)$ whereas carbonates $(3.3,1,0.4,0.6$ and 0.6$)$ and exchangeable $(1.3,1.3,0.5,0.9$ and 0.5 ) contributed the lowest Chromium. 


\section{Cobalt (Co)}

The results in Table 2 shown that moderately low percentage contributions of the Co were afforded by oxidisable $(3,8,3,6$ and 4$)$, carbonates $(5,7,9,9.3$ and 15), reducible $(6,7,9,9$ and 12) and exchangeable except in S-1 in which the contribution of the exchangeable observed was high (37, 6, 7, 7.2 and 11). The highest percentage contribution of Co was found in the residual fraction (50, 56, 62, 55 and 58). The abundance of $\mathrm{Co}$ in the residual fraction reported in this studied was similar to the Gibb, 1977 report on suspended sediments of two large non - polluted rivers, the Amazon and Yukon, where 13- 19\% of Co was bound to organic matter, $27-29 \%$ to $\mathrm{Fe}-\mathrm{Mn}$ oxides and $44-51 \%$ in crystalline particles (residual fraction).

\section{Discussion}

The result of the present study (Table 1) indicates that sequential extraction procedure despite its inherent limitations does lend itself to the study of the geochemical behavior of different trace metals in the sediment. It highlights areas where anomalously high concentration of particulate trace metals may adversely affect water quality or biota.

Exchangeable fraction metals are generally considered to be readily bio-available as they are weakly bound and may equilibrate rapidly with the aqueous phase (Gambrell et al., 1976, Gibb, 1977). In this present study only cadmium and cobalt were found in appreciable proportion in the exchangeable fraction of the studied streams, also observed in reasonable percentage in the fraction were $\mathrm{Pb}, \mathrm{Zn} \mathrm{\&} \mathrm{Cu}$ in the stream sediment sample of Odo - Ona (S-1).

Therefore, between the readily available (exchangeable) fraction and the unavailable lithogenous (residual) fraction trace metals, there exist a number of geochemical phases that may potentially releases trace metals, these are fraction 2 - 4, that is Carbonate, Reducible (Fe - Mn oxide) and Oxidisable ( organic matter bound) fractions. They constitute most important pools of potentially available trace metals which their released depend on existence of suitable physiochemical factors such as Redox potential, Temperature and $\mathrm{pH}$ of the medium (Gambrell et al., 1976). However, bioavailability of metals in the geochemical fractions decreases as follow; exchangeable $>$ carbonate $>$ reducible $>$ oxidisable $>$ residual.

Moreover, in accordance with Tessier et al., 1979 defined model for heavy metal association with geochemical fractions the first four fractions mentioned above are considered as potential available fractions (readily available for plants uptake and biota bio- accumulation).

\section{Mobility and Bioavailability of the studied heavy metals}

Exchangeable fraction metals are the most liable metal phase in geochemical fractions of both soils and sediments. Metals in the fraction adsorbed weakly to the geochemical fraction. In this study Odo-ona stream (S1) exhibited the highest percentage of heavy metals in the exchangeable geochemical fraction $(\mathrm{Zn}(38.0 \%), \mathrm{Cu}$ (16.0\%), Cd (13.8), Ni (5.0\%), Pb (14.8\%), Cr (1.3\%), Co (36.6\%)) in almost all the present studied streams except $\mathrm{Cd}(21.1 \%)$ in Kudeti. The exchangeable fraction $\mathrm{Zn}, \mathrm{Co}, \mathrm{Cu}, \mathrm{Pb}, \mathrm{Cd}$, and $\mathrm{Ni}$ in this studied has shown reasonable contribution and may be a potential health risks.

Carbonate Fraction metals are the next easily available metals in sediment geochemical phases. The heavy metals adsorbed to this geochemical phase could be easily released by ion- exchange effect / change in $\mathrm{pH}$ of the medium.

Meanwhile, mobility and bioavailability with respect to the total of the percentage (\%) of all nonresidual fractions metals concentration observed in each of all the studied streams gave the following orders of decreasing mobility

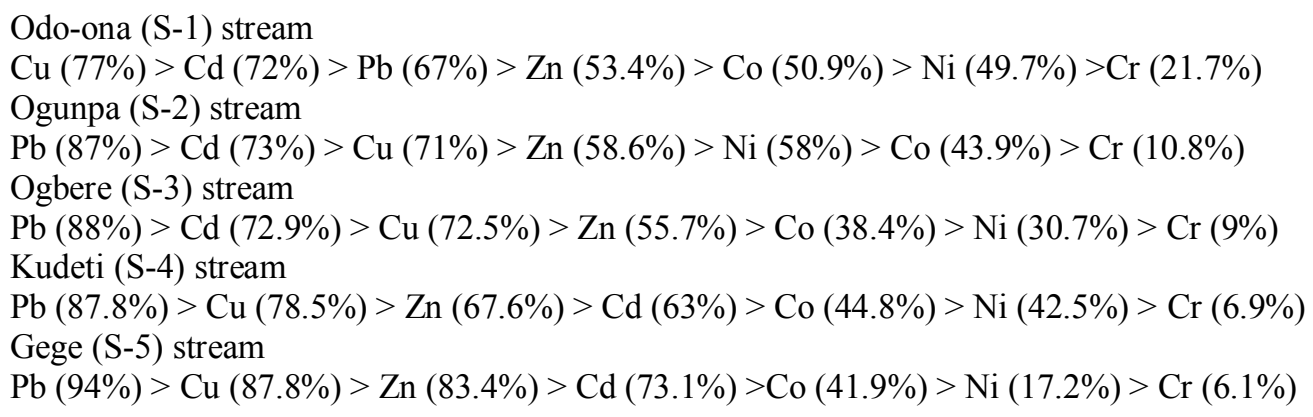

The presence of higher percentage $(\%)$ of $\mathrm{Pb}, \mathrm{Cd}, \mathrm{Cu}, \mathrm{Zn}$, $\mathrm{Co}$ and $\mathrm{Ni}$ metals in the non - residual fractions is an indication of environmental risk because they may be easily transferred into the food chain through water reservoirs and uptake by plants and aquatic biota in the studied water bodies. Association of more than $50 \%$ of the $\mathrm{Pb}, \mathrm{Cd}, \mathrm{Cu}, \mathrm{Zn}$ and $\mathrm{Ni}$ total metal percentage concentrations with the non residual fractions in 
this study suggested that they are from anthropogenic activities and a thing of greater environmental concern for all the studied streams of Ibadan metropolis. Chromium $(\mathrm{Cr})$ is the least available of all the metals studied in all the studied streams, follow by Cobalt (Co) and Nickel (Ni).

The order of decrease in availability $\mathrm{Cr}$, Co and $\mathrm{Ni}$ in all the studied streams were as follow;

Chromium; Odo - ona $(21.7 \%)>$ Ogunpa $(10.8 \%)>$ Ogbere $(9 \%)>\operatorname{Kudeti}(6.9 \%)>$ Gege $(6.1 \%)$

Cobalt; Odo - ona (50.4\%) > Kudeti (44.8\%) > Ogunpa (43.9) $>$ Gege $(41.9 \%)>$ Ogbere $(38.4 \%)$

Nickel; Ogunpa $(58 \%)>$ Odo - ona $(49.7 \%)>$ Kudeti $(42.5 \%)>$ Ogbere $(30.7 \%)>$ Gege $(17.2 \%)$

Therefore, since more than $50 \%$ of $\mathrm{Cr}$, $\mathrm{Co}$ and $\mathrm{Ni}$ metals were observed in Lithogenous / residual fraction of all the studied stream of Ibadan metropolis except in the case of Co (49.6\%) in Odo -ona (S-1) stream and $\mathrm{Ni}(42 \%)$ in Ogunpa (S-2) stream, the main source of the metals (Cr, Co and $\mathrm{Ni})$ in the sediments of the studied streams may be attributed to rock and soils weathering, and they are not easily available for plants and aquatic biota uptakes talk less of contaminating water bodies through remobilization.

The results in Table 2 and Figure 2 on the percentage concentrations of available $\&$ non - available heavy metals in sediments of studied streams of Ibadan metropolis, have shown clearly that there is tendency for the studied streams to be heavily polluted with the studied heavy metals in the following order $\mathrm{Pb}>\mathrm{Cu}>\mathrm{Cd}$ $>\mathrm{Zn}>\mathrm{Co}>\mathrm{Ni}>\mathrm{Cr}$ in future if the Redox potential, temperature and $\mathrm{pH}$ of the studied streams changes in favour of releasing / remobilizing the metals from the fractions $1-4$ (available fractions), due to the fact that above $50 \%$ of these heavy metals associated with the fractions(1-4), except Chromium of all the streams sediment studied, Cobalt in (S-3), (S-5), (S-2) \& (S-4) and Nickel of the following streams (S -3), (S- 4) \& (S5) that exhibited less than $50 \%$ (Tables $1 \& 2$ ).

\section{Conclusion}

The presence of more than $50 \%$ of $\mathrm{Pb}, \mathrm{Cd}, \mathrm{Cu}, \mathrm{Zn}$ in non- lithogenous phase (that is sum of exchangeable, carbonate, reducible and oxidisable fractions) of all the studied streams, Cobalt in (S-1) and Nickel in (S-2) indicates the influence of anthropogenic activities. Therefore, they are readily available for plants and aquatic biota uptakes and could be of greater environmental risks. However, $\mathrm{Cr}, \mathrm{Co}$ and $\mathrm{Ni}$ in all the studied streams of Ibadan metropolis except $\mathrm{Co}$ and $\mathrm{Ni}$ of (S-1) and (S-2) streams respectively were influenced by rock and soils formation or weathering since more than $50 \%$ of them were found in the lithogenous phase (residual fraction) of the sediments. They are not easily available for uptakes therefore, suggested no environmental risks under natural conditions.

\section{Acknowledgment}

The author is grateful to the Nigerian Institute for Oceanography and Marine Research, Nigeria, Prof. P.C. Oniawa and Department of Chemistry, University of Ibadan, Ibadan, Nigeria for their support and use of their facilities.

\section{References}

[1]. A.V. Filgueiras, I. Lavilla and C. Bendicho (2002) Chemical Sequential Extraction for metal Partitioning in environmental solid samples. J. Environ. Monit. 4, 823-857.

[2]. Ashraf MA, Maah, M.J., Yusoff, I. (2012) Chemical Speciation and Potential Mobiity of Heavy Metals in the Soil of Former Tin Mining Catchment. Scientific World Journal. 2012; 2012: 125608 (Published Online).

[3]. Badri, M.A. and Aston, S.R. (1983). Observation of heavy metal geochemical associations in polluted and non - polluted estuarine sediments. Environ. Pollution; 6 (series B); 181 - 193.

[4]. Bhupander Kumar, Sanjay Kumar, Meenu Mishra, S.K. Singh, Dev Prakash, C.S. Sharma and D.P. Mukherjee (2011) Geochemical fractionation of some heavy metals in the soil in the vicinity Sukinda mining Area, Orissa. Advances Applied Science Research, Pelagia Research Library. 2 (5): 263- 272.

[5]. Brannon, J.M., Engler, R.M., Rose, J.R., Hunt, P.G. and Smith, I. (1976). Distribution of toxic heavy metals in marine and fresh water sediments; American society of civil Engineers, New York, N.Y.455 - 495.

[6]. Chester, R. and Messiha - Hanna, R.G. (1970). Trace element partition patterns in North Atlantic deep - sea sediments; Geochemical et Cosmochimica Acta, 34, $1121-1128$.

[7]. Forstner, U. and Wittmann, G.T.W. (1981). Metal pollution in aquatic environment (2 ${ }^{\text {nd }}$ edition) Springer Verlag; Berlin; $81-120$.

[8]. Gambrell R.P. (1994) Trace and Toxic metals in Wetland - A review. J. Environ. Qual. Vol. 23, pp 883- 891.

[9]. Gibb, R.J. (1977). Transport phases of transition metals in the Amazon and Yukon rivers, Geological society of America Bulletin, $88,829-843$.

[10]. Grieve D. and Fletcher, K. (1977). Interactions between Zinc and suspended sediments in the Fraser river estuary, British Columbia. Estuarine and coastal marine science, 5, 415-419.

[11]. Gupta, S.K. and Chen, K.Y. (1975). Partitioning of Trace metals in selective chemical fractions of near shore sediments. Environmental Letter, 10, $129-158$.

[12]. Haung J, Haung R, Jiao JJ, Chen K. Speciation and mobility of heavy metals in mud, in coastal reclamation areas in Chenzhen, China. Environment Geology. 2007; 53(1):221-228.

[13]. P. O'Neill, J. Williams, K. C. C. Bancroft, R. D. Davies and J. A. Campbell, Int. Conference on Heavy Metals in the Environment, Athens, Greece, 1985, vol. 1, p.582

[14]. S. Zauyah, B. Juliana, R. Noorhafizah, C.I. Fauziah and A.B. Rosenani (2004) Concentration and Speciation of Heavy Metals in some Cultivated and Uncultivated Ultisols and Ineptisols in Peninsular Malaysia. Supersoil 2004: $3^{\text {rd }}$ Australian New Zealand Soils Conference, 5-9 December, 2004, University of Sydney, Austrialia. Published on CDROM. Website: www.regional.org.au/au/asssi// 
[15]. Schlinder, P.W. (1991) The regulation of heavy metal concentrations in the natural aquatic systems. In Heavy Metals in the Environment 1. (Ed) Vernet J - P. Elsevier Amsterdam, London. New York and Toyko, pp 95-124.

[16]. Serife Tokaliogu, Senol Kartal and Gokhan Birol (2003) Application of a Three- stage Sequential Extraction procedure for the Determination of Extractable Metal Contents in Highway Soils. Turk. J. Chem. 27, 333- 346.

[17]. Singh A.K; Hasnain S. I; Banerjee D.K (1999). Grain size and Geochemical Partitioning of Heavy metals in Sediments of the Damodar River, a tributary of the lower Ganga India. Environmental Geology 39(1).

[18]. Smith, R.M. and Martell, A.E. (1976). Critical stability constants in organic complexes, plenums press New York.4, 257.

[19]. Stumm, W and Morgan, J.J. (1981). Aquatic chemistry, an introduction emphasizing chemical equilibrium in natural, (2 $2^{\text {nd }}$ edition), water wiley -inter science, New York. 583

[20]. Tessier, A Campbell, P.G.C Bisson, M (1979) Sequential Extraction procedure for the Speciation of Particulate Trace metals. Anal. Chem. 51, 844-851

[21]. Xian, X. (1989) Chemical partitioning of Cadmium, Zinc, lead and copper in soils near smelters. J. Environ. Sc Health A 6: 527541 . 